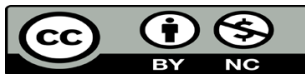

\title{
O HABEAS DATA E A CONCRETIZAÇÃO DO DIREITO À PROTEÇÃO DE DADOS PESSOAIS NA METÓDICA CONSTITUCIONAL DE FRIEDRICH MÜLLER
}

\author{
THE HABEAS DATA AND THE REALIZATION OF THE RIGHT \\ TO PERSONAL DATA PROTECTION ACCORDING TO THE \\ CONSTITUTIONAL METHODICAL OF FRIEDRICH MÜLLER
}

Marco Aurélio Rodrigues da Cunha e Cruz

Matheus Felipe de Castro

\section{RESUMO}

O problema a ser pesquisado é a forma como a protecção de dados pessoais foi abordada pela jurisprudência do Supremo Tribunal através de habeas data. A hipótese a ser desenvolvida é a defendida no julgamento do Recurso Extraordinário 673.707: a "vitalização" de habeas data como uma garantia constitucional do direito fundamental à proteção de dados pessoais. Objetivase analisar a concretização do habeas data como uma garantia constitucional do direito fundamental à protecção de dados pessoais na jurisprudência do Supremo Tribunal Federal, de acordo com a metódica constitucional de Friedrich Müller.

Palavras-chave: Habeas data. Proteção de Dados pessoais. Metódica constitucional.

\section{ABSTRACT}

The problem to be researched is how the protection of personal data was addressed by the Supreme Court's case law through habeas data. The hypothesis 
to be developed is advocated in the judgment of "Extraordinary Appeal" 673.707: the "vitalization" of habeas data as a constitutional guarantee for the fundamental right to personal data protection. The goal of this paper is to examine the concretion of habeas data as a constitutional guarantee for the fundamental right to protection of personal data on the Supreme Court's case law, according to the constitutional methodical of Friedrich Müller.

Keywords: Habeas data. Data protection. Constitutional methodical.

\section{INTRODUÇÃO}

Uma série acontecimentos nos úlitmos três anos (de 2015 a 2017) fizeram a proteção de dados pessoais protagonizar, em determinado momento, evidência transnacional, legislativa e jurisprudencial. Sob a perspectiva trasnacional, o Conselho de Direitos Humanos da ONU, com a Resolução A/HRC/28/L.27, decidiu nomear um Relator Especial sobre o direito à privacidade por um período de três anos, o Professor Joseph A. Cannataci (UNITED NATIONS HUMAN RIGHTS COUNCIL, 2015A; UNITED NATIONS HUMAN RIGHTS COUNCIL, 2015B). Já foram produzidos alguns relatórios. 0 primeiro (A/HRC/31/64) descreve a proposta do mandato, dos métodos e um plano de trabalho de três anos, além de uma visão geral do "estado da arte" da privacidade no início de 2016 (UNITED NATIONS HUMAN RIGHTS COUNCIL, 2018A). 0 segundo, A/HRC/34/60, contém notas sobre as atividades de vigilância governamental desde uma perspectiva nacional e internacional (UNITED NATIONS HUMAN RIGHTS COUNCIL, 2018A). Em 2018, está prevista a redação de relatório ao Conselho de Direitos Humanos da ONU sobre algumas opções preliminares de governança da Internet para a configuração de um instrumento jurídico internacional que trate sobre a vigilância governamental. (UNITED NATIONS HUMAN RIGHTS COUNCIL, 2018B).

Em 6 de outubro de 2015 o Tribunal de Justiça da União Europeia declarou que o US Safe Harbour era inválido por ter nível inadequado de proteção de dados pessoais (TRIBUNAL DE JUTIÇA EUROPEU, 2015). Em 12 de julho de 2016 a Comissão adotou um novo acordo transnacional para "transferência transatlântica de dados" com os Estados Unidos, 
o Privacy Shield (EUROPEAN COMISSION, 2016). Em 2016, entrou em vigor a Diretiva Europeia n. 680/16 e o Regulamento de Proteção de Dados Pessoais n. 679/16, cujos efeitos tem previsão para surtir a partir de maio de 2018.

No contexto legiferante interno, destaca-se a consulta pública promovida pelo Ministério da Justiça (MJ), entre os dias 28 de Janeiro a 5 de julho, sobre o Anteprojeto de Proteção de Dados Pessoais, com versão final proposta em 20 de outubro de 2015 pela Senacon e a Secretaria de Assuntos Legislativos-MJ (BRASIL, 2015). 0 Poder Executivo apresentou à Câmara dos Deputados em 13 de Maio de 2016 um Projeto de Lei (PL) sob o n. 5276/2016. Em 2016, a Lei № 12.965, de 23 de abril de 2014 (Marco Civil da Internet), foi objeto de regulamentação por meio do Decreto 8.771, de 11 de maio de 2016; na mesma data em que a Política de Dados Abertos do Poder Executivo foi instituída pelo Decreto 8.777/16. Ainda, foi disciplinado o compartilhamento de bases de dados na administração pública federal com o Decreto no 8.789, de 29 de junho de 2016. Em 2017, foram realizadas audiências públicas e um seminário internacional com o fito de apoiar os trabalhos da Comissão Especial da Câmara dos Deputados (PL 4060/2012 e PL 5275/2016). A conjugação destes dois projetos originou a Lei de Proteção de Dados Pessoais (Lei 13.709/18), com previsão de vigência a partir de 2020.

Em sede jurisprudencial nacional o protagonismo se deu na decisão do Pleno do Supremo Tribunal Federal (STF) no RE 673.707 (RE 673.707 RG/MG, Relator: Min. LUIZ FUX, julgado em 17.06.2015, Tribunal Pleno, DJe-195, divulgado em 29.09.2015, publicado em 30.09.2015), em que se discutiu se o habeas data é a garantia constitucional adequada para a obtenção dos dados concernentes ao pagamento de tributos do próprio contribuinte constantes dos sistemas informatizados de apoio à arrecadação dos órgãos da administração fazendária dos entes estatais.

Diante da cronologia destes fatos é indiscutível admitir a relevância da aplicação dos paradigmas de direitos humanos/direitos fundamentais para a proteção de dados pessoais, no contexto do direito à privacidade. Contudo, a proteção de dados pessoais no Brasil não tem sido produto de uma única fonte legislativa específica. Sua configuração jurídicoconstitucional fora interpretada no Brasil com a inclusão do habeas 
data no inciso LXXII do art. $5^{\circ}$, da Constituição Federal de 1988, e com a positivação da Lei 9.507/97, além de outros atos legislativos. Não havia um corpus legis único que disciplinasse a proteção de dados pessoais. A insuficiência legiferante nacional potencializou o problema científico de se meditar sobre a proteção de dados pessoais. Isso porque a incessante busca de formas de acesso e de controle a/de dados pessoais sobre o sujeito se justifica pela necessidade que os entes públicos e privados requerem para as projeções sociais, políticas, econômicas e/ou jurídicas. É imperiosa, pois, uma reposta jurídica tanto para garantir direitos aos titulares como para responsabilizar quem comete condutas antijurídicas.

Diante de tais considerações, sobressai a relevância do aludido RE 673.707. O STF voltou sua atenção para a efetividade do habeas data ao decidir se tal garantia constitucional seria ou não um meio de efetivação do direito fundamental à proteção dos dados pessoais. 0 Ministro Marco Aurélio Mello observou que em 25 anos de Supremo nunca havia Julgado o mérito de um habeas data. 0 Ministro Gilmar Mendes afirmou ser "talvez, o marco inicial de uma vitalização do habeas data, numa percepção mais ampla, [...] já falando de um direito fundamental à autodeterminação informativa $[\ldots]$ ".

É sobre essa intervenção que versa a problematização deste escrito: a forma como a proteção dos dados pessoais foi tangenciada na jurisprudência do STF por meio do habeas data, a garantia constitucional indicada pelo poder constituinte para a tutelar esse bem jurídico. A hipótese a ser desenvolvida é a propugnada no RE 673.707: a "vitalização" do habeas data como instrumento/garantia constitucional do direito fundamental à proteção de dados pessoais. Será adotada a metódica constitucional de Friedrich Müller $(2005,2011,2013)$ como referencial teórico-metodológico.

O objetivo deste texto, portanto, é examinar a concreção do habeas data como garantia constitucional do direito fundamental à proteção dos dados pessoais, a partir da análise de um recorte da realidade na jurisprudência do STF (conjunto de fatos afetados por um preceito, parcela da realidade a se regular). Para Müller (2005, p. 5) a jurisprudência pode oferecer um material "suficientemente abrangente e consistente para permitir um acompanhamento confiável de concepções e tendências 
referentes ao método", que serve de um valor paradigmático em termos de conhecimento (MÜLLER, 2005, p. 46). Ao divergir do paradigma positivista, Müller (2005, p. 124-125) defende que "a Constituição e a sua concretização são aqui vinculadas integrativamente $a$ limine. Esse processo parte dos textos das normas (e dos casos jurídicos) e encontra neles os seus limites [...]."

Para ilustrar esta assertiva, Müller (2005) utiliza a jurisprudência do Tribunal Constitucional Federal como representativa da jurisprudência constitucional da República Federal da Alemanha. A despeito da diferença dos modelos de controle de constitucionalidade entre Brasil e Alemanha, neste texto se optou por seguir a jurisprudência do Supremo Tribunal Federal para abordar o objeto de pesquisa, o habeas data.

Para a condução do presente artigo científico, as seguintes estratégias foram utilizadas: (i) pesquisa bibliográfica: levantamento bibliográfico sobre os conceitos e análises do direito à proteção de dados pessoais e do habeas data; (ii) pesquisa documental: subsidiou a coleta de dados, por meio de pesquisa das decisões disponibilizadas no website do STF; (iii) aplicação da metódica constitucional de Friedrich Müller, a seguir melhor explicada.

\section{A METÓDICA CONSTITUCIONAL DE FRIEDRICH MÜLLER}

A metódica elaborada por Friedrich Müller pugna por uma análise da jurisprudência como uma "concepção de tipo novo da efetivação do direito. Esta concepção de concretização abrange simultaneamente os fatores da realidade e da norma, são estruturados segundo o "âmbito da norma" e a ideia normativa orientadora (programa da norma)" (MÜLLER, 2011, p. 16). Müller (2011, p. 17) busca a normatividade dos institutos ou "qualidade dinâmica de uma norma assim compreendida, tanto de ordenar à realidade que lhe subjaz - normatividade concreta - quanto de ser condicionada e estruturada por essa realidade - normatividade materialmente determinada". É intuitivo, portanto, perceber que Müller refuta a separação entre norma e fatos, Direito e realidade. Com este raciocínio, Müller admite que "a jurisprudência constitucional permite 
descobrir o valor que os elementos do âmbito normativo podem adquirir tanto para o conhecimento concreto como para o desenvolvimento da dogmática jurídico-constitucional" (2013, p. 28).

Em "Métodos de trabalho no direito constitucional", o conceito de "metódica" inclui a hermenêutica, a interpretação, os métodos de interpretação e a metodologia. A hermenêutica se refere às condições de princípio, os pressupostos epistemológicos e de teoria do direito para a concretização jurídica normativamente vinculada do direito. A interpretação alude aos possíveis tratamentos jurídico-filológicos dos textos de normas. E a metodologia se vocaciona para a totalidade das regras técnicas da interpretação no trato com as normas jurídicas. Müller consente que uma norma jurídica é mais do que seu texto de norma e, por isso, a concretização prática da norma é mais do que a intepretação do texto. Desta maneira, em princípio, a "metódica" avoca "todas as modalidades de trabalho da concretização da norma e da realização do direito” e, neste sentido, “[...] uma metódica do direito constitucional diz respeito à concretização da Constituição pelo governo, administração pública e legislação em medida não inferior da concretização operada pela jurisprudência e pela ciência do direito" (MÜLLER, 2005, p. 2-3).

Outrossim, Müller (2005, p. 27-28) defende que os problemas de concretização jurídica não podem ser respondidos mediante a "aplicação" "de prescrições prontas de decisões voluntaristas preexistentes, nem pela 'subsunção' e pela inferência silogística com ajuda dos cânones savignyianos". Reconhece que as regras da interpretação de Savigny não foram forjadas para o Direito Constitucional e que estas poderiam ser "pontos de vista auxiliares de fecundidade variável conforme a peculiaridade das normas jurídicas concretizandas” (MÜLLER, 2005, p. 27-28).

0 argumento de Müller (2005) rechaça, portanto, a lógica da mera positividade do direito, pois esta se aparta da realidade da vida e reduz ou perde a normatividade jurídica. Müller (2005) se opõe à compreensão de que a norma jurídica é um juízo hipotético, uma premissa maior formalizada segundo os princípios da lógica formal, como vontade material e abstratamente vazia. A sua contestação se fundamenta na afirmação de que Direito e realidade, norma e recorte normatizado da realidade estão justapostos em si no positivismo, sem se relacionar. 
Nesta linha de raciocínio, Müller (2005, p. 38) propõe uma não-identidade (sinônimo/igualdade) entre texto da norma e norma, pois "o teor literal de uma prescrição juspositiva é apenas a 'ponta do iceberg”'. Isso porque a literalidade se presta à formulação do programa da norma, a "ordem jurídica" tradicionalmente assim compreendida. 0 âmbito da norma é entendido como o recorte da realidade social que o programa da norma elegeu para si ou em parte criou para si como seu âmbito de regulação. Este pensamento leva em conta que na concretização do direito, "direito" e "realidade" não são subsistem autonomamente por si. "A ordem e o que por ela foi ordenado são momentos da concretização da norma, em princípio eficazes no mesmo grau hierárquico, podendo ser distinguidos apenas em termos relativos" (MÜLLER, 2005, p. 43-44).

0 âmbito da norma, pois, não é equivalente às particularidades materiais do conjunto dos fatos. Ele faz parte da própria prescrição jurídica, é um fator co-constitutivo da normatividade. Da totalidade da realidade afetada por uma prescrição, do “âmbito material”, o programa da norma destaca o âmbito da norma como componente da hipótese legal normativa. Não é "uma soma de fatos, mas um nexo formulado em termos de possibilidade real de elementos estruturais que são destacados da realidade social na perspectiva seletiva e valorativa do programa da norma" (MÜLLER, 2005, p. 44-45).

A normatividade, portanto, decorre de dados extralinguísticos de tipo estatal-social: "de um funcionamento efetivo, de um reconhecimento efetivo e de uma atualidade efetiva desse ordenamento constitucional para motivações empíricas na sua área." Além da gramaticalidade do texto, a normatividade é composta por "materiais legais, de manuais didáticos, de comentários e estudos monográficos, de precedentes e de material do Direito Comparado, quer dizer, com ajuda de numerosos textos que não são idênticos ao e transcendem o teor literal da norma". Os conceitos jurídicos contidos no texto da norma representam, em determinados casos, descrições factuais. São, pois, conceitos indicadores e articuladores do que se pensa como correspondência na realidade social. "O texto da norma não contém a normatividade e a sua estrutura material concreta. Ele dirige e limita as possibilidades legítimas e legais da concretização". (MÜLLER, 2005, p. 39-41). 
A normatividade, para Müller (2005), é um "processo estruturado". 0 exame da relação entre normatividade, norma e texto da norma, vislumbra-se a partir da análise da estrutura da norma. Com esta linha de pensamento é impossível separar a norma jurídica do caso jurídico por ela regulado, nem o caso da norma. Isso porque ambos fornecem os elementos necessários e complementares à decisão jurídica. Toda e qualquer norma somente faz sentido com vistas a um caso a ser (co) solucionado por ela (MÜLLER, 2005, p. 50).

E para fazer esta complementariedade Müller (2005, p. 56-57) propõe a "metódica estruturante", que relaciona a estrutura de norma, o texto de norma, a normatividade e o processo de concretização "sobre o nexo entre concretização estruturada da norma e as tarefas das funções individuais da prática jurídica, sobre a não-identidade de norma e texto da norma e sobre a não-identidade de concretização e interpretação." Dividem-se em dois os grupos de elementos de concretização. 0 primeiro se refere ao tratamento do texto da norma, incluindo a formulação de não-normas em linguagem. 0 segundo está direcionado para os passos da concretização, "teores materiais, que resultam da análise do âmbito da norma da prescrição implementanda e da análise dos elementos do conjunto de fatos destacados como relevantes no processo de concretização por via de detalhamentos recíprocos." (MÜLLER, 2005, p. 59).

A metódica constitucional de Müller, portanto, procede a concretização da Constituição com os seguintes elementos: (a) elementos metodológicos strictiore sensu (gramatical, histórico, genético, sistemático, e teleológico) e os princípios da interpretação da Constituição; (b) elementos do âmbito da norma; (c) elementos dogmáticos; (d) elementos de teoria; (e) elementos de técnica de solução; e (f) elementos de política do direito e política constitucional (MÜLLER, 2005, p. 59 e 105-106).

Com esta perspectiva metódica, Müller (2005, p. 37-38) busca decompor os processos da elaboração da decisão e da fundamentação expositiva em "passos de raciocínio suficientemente pequenos para abrir o caminho ao feed-back controlador por parte dos destinatários da norma, dos afetados por ela, dos titulares de funções estatais e da ciência jurídica". É dentro desta proposta metodológica que se pautará a propugnada hipótese no RE 673.707, ou seja, a "vitalização" do habeas data como 
instrumento/garantia constitucional do direito fundamental à proteção de dados pessoais.

\section{O HABEAS DATA E A CONCRETIZAÇÃO DO DIREITO À PROTEÇÃO DE DADOS PESSOAIS NO RE 673.707 SEGUN- DO A METÓDICA ESTRUTURANTE}

As regras tradicionais de interpretação, para Müller, configuram elementos metodológicos strictiore sensu, facetas distintas de uma norma concretizanda no caso. Resultam como questões a uma prescrição. A gramatical é a primeira das regras tradicionais de interpretação.

O texto da norma tem um significado e um alcance que "não são dados pelo arbítrio imaginoso do intérprete, mas são, ao contrário, revelados pelo exame imparcial do texto." (REALE, 2004, p. 279). Para Müller (2005, p.64-66), esta regra indica que o texto de norma constitucional limita a extensão da concretização juridicamente admissível, pois “O teor literal demarca as fronteiras extremas das possíveis variantes de sentido, i. e., funcionalmente defensáveis e constitucionalmente admissíveis" e o modo com que "o texto expressa de forma linguisticamente confiável o espaço de ação para os enunciados normativos, o resultado não pode contrariar as possibilidades de solução remanescentes nesse espaço de ação". Müller (2005, p. 62) observa que há de se ater à estrutura do texto da norma para constatar se o texto da norma se afigura "menos claro", "mais amplo" ou "mais indeterminado".

Parte-se, portanto, do pressuposto de que a ordem das palavras e o modo como elas estão conectadas são importantes para obter-se o correto significado. 0 tratamento do texto da norma, pois, é apenas o ponto de partida da atividade metódica e compõe o "programa da norma". A interpretação gramatical obriga, pois, a examinar as equivocidades proporcionadas pelo uso das línguas naturais e suas imperfeitas regras de conexão léxica (FERRAZ JUNIOR, 2014, p. 252-253).

A expressão habeas data é utilizada de maneira análoga à terminologia do habeas corpus. Recorde-se que esta última significa que se "tenha, traga, exiba ou apresente corpo (ante o juiz)", enquanto que no caso do 
habeas data se quer conotar "que se tenha, traga, exiba ou apresente os dados" (BAZÁN, 2005). A locução habeas data se forma com habeas, segunda pessoa do presente do subjuntivo de habeo. Habere significa tenha posse (PIERINI; LORENCES, TORNABENE, 1999). Habeas une-se o vocábulo data, a respeito do qual existe uma disputa léxica. Para alguns, data é o acusativo neutro plural de datum (também do latim), representação convencional de fatos, conceitos ou instruções de forma apropriada para a comunicação e o processamento por meios automáticos (PIERINI; LORENCES, TORNABENE, 1999). Outros advogam que a palavra data é proveniente do inglês, com o significado de informação ou dados (BAZÁN, 2005). Habeas data converge com a ideia, portanto, de um direito a decidir por si mesmo, com as exceções de interesse público, quando, em que termos e onde os dados que lhe concernem devem ser revelados (PIERINI; LORENCES, TORNABENE, 1999).

Convém, pois, fazer uma citação direta do texto do inciso LXXII, do artigo 5 , da Constituição de 1988:

LXXII - conceder-se-á habeas data:

a) para assegurar o conhecimento de informações relativas à pessoa do impetrante, constantes de registros ou bancos de dados de entidades governamentais ou de caráter público;

b) para a retificação de dados, quando não se prefira fazê-lo por processo sigiloso, judicial ou administrativo;

0 verbo "conceder", a primeira vista, condiciona as duas possibilidades de exigibilidade jurídica de se requerer o habeas data. Tais possibilidades configuram "o espaço de ação para os enunciados normativos". O programa da norma do habeas data, pois, indica dois espaços de ação.

O primeiro espaço de ação é o de "assegurar" o objeto ou a matéria do que se garante com o habeas data: "o conhecimento de informações relativas à pessoa do impetrante”. Esta primeira parte da redação também indica uma limitação da parte legítima para se requerer a ação constitucional, pois não são quaisquer informações, mas somente as "relativas à pessoa do impetrante", não de outrem. A literalidade, a priori, condiciona a legitimidade ativa da impetração do objeto do habeas data ao titular das informações as quais se quer ter conhecimento. Ademais, o primeiro 
espaço de ação direciona a legitimidade passiva: sugere que será exigível juridicamente por meio do habeas data que se tenha conhecimento quando as informações do titular constem em "registros ou bancos de dados de entidades governamentais ou de caráter público".

O segundo espaço de ação parece ampliar ("mais amplo") o direito do titular das informações a que se quer ter conhecimento. Isso porque "assegurar o conhecimento" não tem o mesmo significado de "retificação de dados". 0 impetrante, portanto; além de verificar, consultar e/ ou ter ciência; pode "retificar" os dados que constam nos "registros ou bancos de dados de entidades governamentais ou de caráter público". A expressão "quando não se prefira fazê-lo por processo sigiloso, judicial ou administrativo" reforça a faculdade do titular das informações de poder impetrar o habeas data, ainda que haja a possibilidade/faculdade jurídica de retificar os seus dados pessoais por processo sigiloso (judicial ou administrativo). 0 sigilo do processo judicial ou administrativo contrasta, portanto, com a publicidade que a gramaticalidade desta alínea "b" quer empregar ao habeas data.

A interpretação literal do texto da norma, neste tom, apresenta "dois espaços de ação" para o enunciado normativo do habeas data, nos quais se vislumbram o "programa da norma": (i) o objeto (informações relativas à pessoa do impetrante); (ii) a legitimidade (titular das informações pessoais e registros ou bancos de dados de entidades governamentais ou de caráter público), (iii) as faculdades jurídicas exigíveis (assegurar o conhecimento e retificação de dados); e (iv) a publicidade do processo.

Sem embargo, a gramaticalidade não pode ser dissociada dos elementos históricos, genéticos, sistemáticos e teleológicos. A interpretação dos textos não-normativos (elementos genético e histórico) é auxiliar ao aspecto gramatical, pois com ela se responde à indagação de como se chegou à redação do texto da norma, mas também estão integralmente entrelaçados a outros aspectos, quanto ao seu objeto (MÜLLER, 2005, p. 66). A despeito da interpretação histórica e a interpretação genética representarem, por vezes, subcasos da interpretação sistemática (MÜLLER, 2005, p. 70), os pontos de vista delas emergidos não tem sede em outras prescrições do direito vigente. 
Quanto ao elemento histórico, verifica-se que não houve texto de norma sobre habeas data ao se levantar uma comparação em Constituições brasileiras anteriores. Não existem, pois, publicações teóricas, legislação ou jurisprudências de âmbito nacional anteriores a esta data (NIESS, 1990; DALLARI, 2002). A inovação de inclusão de texto de norma constitucional "habeas data" também se aplica a Constituições estrangeiras (FOLGOSI; NUSDEO, 2011). Com nomenclatura diversa, instrumentos semelhantes foram também previstos na Constituição de Portugal de 1976 (art. 35) e na Constituição Espanhola de 1978 (art. 105, b).

O elemento genético noticia que a inserção do habeas data no texto constitucional surgiu como reação ao uso institucional autoritário da informação (GUERRA FILHO, 1998; LOBATO, 1996; DONEDA, 2008). Conforme recorda Dalmo de Abreu Dallari (2002), foi estabelecido um sistema de informações sigilosas, "quase todos falsos ou mentirosos", tendo como vértice o Serviço Nacional de Informações - SNI. Os registros eram inacessíveis, pois considerados sigilosos por motivo de segurança nacional. 0 momento da concepção desta garantia constitucional era oporturno à abertura dos arquivos da "ditadura", para que se pudesse ter noção ou retificar dados próprios que o regime anterior preservara em nome da segurança nacional (PINTO FILHO, 2002).

Propôs-se, pois, na Comissão Provisória de Estudos Constitucionais, presidida por Afonso Arinos de Mello Franco, uma ação constitucional para garantir eficácia ao direito de acesso às informações registradas por entidades públicas e particulares sobre as pessoas. Seu idealizador foi José Afonso da Silva, com contributo da obra "La tutela penal de la intimidad" de Fermín Morales Prats ${ }^{1}$, que usa o termo para se referir ao próprio direito de intimidade contra usos indevidos de registros informáticos (FOLGOSI; NUSDEO, 2011) ${ }^{2}$. No Anteprojeto de Constituição figurou-se o direito à proteção de dados pessoais (art. 17) e o remédio constitucional específico para a fruição deste direito, o habeas data (art. 31). Deveria ser um procedimento diferente dos comuns, similar ao Habeas Corpus. Esta ação teria como finalidade garantir ao interessado acesso às informações e referências a seu respeito, registrada por entidades públicas e particulares e a retificação dos dados eventualmente 
incorretos. (FOLGOSI; NUSDEO, 2011). Entretanto, o direito material não foi previsto, somente a ação constitucional (DONEDA, 2008; SILVA, 2009).

De todos os modos, o habeas data serviu de referência a outros ordenamentos latino-americanos, como Paraguai, Peru, Argentina, Bolívia e Uruguai (GUERRA FILHO, 1998; BAZÁN, 2005; DONEDA, 2008; MAIA, 2012). Danilo Doneda (2008) aponta que o habeas data teve especial ressonância em países latino-americanos na década de 1980, sociedades recém-saídas de regimes militares, marcadas pelo uso hermético da informação. 0 habeas data, como instrumento para o requerimento de informações/dados pessoais registrados em órgãos do poder público, surgiu para "a tutela dos direitos fundamentais envolvidos como também pelo seu importante papel na formação de uma cultura democrática” (DONEDA, 2008, p. 14-33) ${ }^{3}$.

Neste contexto, cumpre aludir ao Parecer n. 5 R. 71, de outubro de 1988, lavrado por Saulo Ramos (1988), a época Consultor Geral da República, que aborda o habeas data. A questão se referia à requisição judicial de informações ao SNI, formulada pelo Juiz Federal da $1^{\text {a }}$ Vara da Seção Judiciária de Pernambuco (CERQUEIRA CÉSAR, 1991). Saulo Ramos (1988) opina que os postulados do constitucionalismo se entrelaçam no equilíbrio entre dois valores que guardam uma tensão dialética: a liberdade e a autoridade. Caracteriza a ordem democrática como um "regime do poder visível", cujo modelo político-jurídico "rejeita (a) o poder que oculta e (b) o poder que se oculta". Contudo, admite que a publicidade dos atos estatais não é uma premissa jurídica absoluta, pois o próprio texto constitucional positivou um "núcleo temático de matérias cujo sigilo seja imprescindível à segurança da sociedade e do Estado, absolutamente imune ao conhecimento de terceiros". Observa que "as informações coligadas pelo SNI, no desempenho de sua função de assessoramento ao Presidente da República, só a esse se destinam, segundo a lei vigente". Defende que "[...] os registros do SNI, consubstanciadores de informações reservadas exclusivamente destinadas ao conhecimento pessoal do Presidente da República, são objetivamente imunes ao livre acesso de qualquer pessoa, órgão ou Poder do Estado". Neste tom, imputa o juízo de fornecer o acesso de informações ou dados pessoais ao talante do Chefe do SNI. 
Ainda como registro de elemento histórico e genético, urge consignar que logo que promulgada a Constituição Federal de 1988 foram impetrados 03 habeas data (RHD22, RHD24, HD18-Q0) para que fosse assegurado o conhecimento de informações/dados que constavam no antigo Serviço Nacional de Informações (SNI). Todos foram declinados em razão da competência do STF (art. 105, I, "b”, CF-88).

Em 06 de outubro, um cidadão, ao relatar sua vida profissional após o Golpe de 1964, impetrou habeas data com fulcro nos incisos XXXIII e LXXII do art. 5을 para que lhe fosse assegurado o conhecimento de todas as informações/dados relativas a si que constavam no SNI. O Pleno do STF demitiu-se da competência originária. Na instância a quo julgou-se extinto o processo, sem resolução de mérito, pois o autor não teria solicitado, administrativamente, as informações/dados ao SNI, configurada portanto a carência da ação por falta de interesse de agir (pretensão resistida). Este caso retornou por meio de recurso (RHD22) e se tornou o paradigmático para a jurisprudência do STF.

Soma-se a este antecedente a impetração de João Baptista Herkenhoff que, em 05 de outubro de 1988, ajuizou habeas data para que o SNI informasse o teor dos registros a seu respeito, ou a sua inexistência, para o fim de pedir retificação no caso de haver incorreções. O habeas data original foi deslocado para o Superior Tribunal de Justiça (STJ), que reconheceu a carência da ação, por falta de interesse de agir (pretensão resistida). A lide também retornou ao STF por via recursal (RHD24).

Na Questão de Ordem no Habeas Data 18 (HD18-QO /RJ, Relator Min. Aldir Passarinho, julgado em 27/04/1989, Tribunal Pleno, DJ de 09.06.1989, p.10095) um ex-militar impetrou a ordem para que tivesse conhecimento das informações que lhe diziam respeito no Centro de Informações da Marinha e do SNI, especialmente sobre as acusações e os motivos da sua demissão da Marinha. Não foi conhecido o pedido, pois incompetente o STF para julgar o feito.

Ainda que indeferidos pela forma como foram impetrados (competência do STF), verifica-se que nos primeiros casos submetidos pelo rito do habeas data há uma coerência argumentativa histórica e genética com o RE 673.707. Foram manjeados ante o Poder Judiciário (iv-publicidade do processo) para que se tivesse a garantia do conhecimento (iii-faculdade 
jurídica exigível) de informações (i-objeto) relativas ao impetrante (iilegitimidade ativa) junto a um bancos de dados de entidade governamental - no caso a SNI (ii-legitimidade passiva). Diante desta convergência, é imperioso inferir que os elementos históricos e genéticos reforçam o elemento gramatical e representam o primeiro espaço de ação do programa da norma do art. $5^{\circ}$, LXXII, "a".

O topos sistemático, para Müller (2005), carece de adicionais pontos de vista auxiliares. Dentro da coerência redacional interna da Constituição de 1988, o habeas data está inserto com as demais garantias constitucionais no primeiro dos cinco capítulos (Capítulo I - Dos Direitos e Deveres Individuais e Coletivos) do Título II (Dos Direitos e Garantias Fundamentais). Como já arrematou J. E. Carreira Alvim (2001), o habeas data, ao lado do habeas corpus e do mandado de segurança, completa "a santíssima trindade" das garantias do Estado Social e Democrático de Direito. De fato, os incisos do art. $5^{\circ}$ que antecedem o texto da norma do habeas data se referem às garantias fundamentais: o habeas corpus; o mandado de segurança e o mandado de injunção. 0 inciso que sucede o texto da norma do habeas data também alude à uma garantia fundamental, a ação popular. O status de garantia fundamental do habeas data lhe impõe a qualidade de limite material de reforma constitucional, pois figura como "cláusula pétrea" do art. 60, § 4º, inciso IV, que aduz literalmente que "Não será objeto de deliberação a proposta de emenda tendente a abolir: [...] IV - os direitos e garantias individuais". In casu, o elemento sistemático converge com as inferências protetivas de concretização obtidas mediante o processo estruturante de interpretação gramatical, histórica, genética no tratamento do texto da norma do art. $5^{\circ}$, LXXII, "a".

Müller (2005, p. 69) entende que o elemento "teleológico" não é um elemento autônomo da concretização. Entretanto, admite que a indagação sobre o "sentido e [pela] finalidade" da norma concretizanda é distinta das que são realizadas com os elementos gramaticais, históricos, genéticos e sistemáticos. É producente introduzir aspectos de "sentido e finalidade" da prescrição a ser trabalhada à medida que são documentáveis com a ajuda de outros elementos. Desta reflexão, há uma confluência de "sentido e finalidade" (elemento teleológico) entre o primeiro "espaço de ação" do texto normativo do habeas data (art. $5^{\circ}$, inciso LXXII, "a") e o recorte 
da realidade suscitado no RE 673.707. Isso porque uma pessoa jurídica queria ter acesso às informações que lhe diziam respeito ao requerer o acesso: (i) às anotações constantes nos arquivos da Receita Federal com relação a todos os débitos de qualquer natureza contidas no Sistema SINCOR ou de qualquer outro onde estiverem registrados; (ii) à relação de todos os pagamentos efetuados para a liquidação de débitos através de vinculação automática ou manual e; (iii) aos pagamentos sem correlação a débitos existentes, disponíveis no banco de dados do órgão público em questão.

Sobre os princípios de interpretação da Constituição, Müller [2005, p. 71-79) argumenta que só são autônomos em grau diminuto e que na sua maior parte se reportam aos aspectos linguístico, histórico, genético, sistemático e teleológico da concretização ${ }^{4}$. Opinião que não é isolada, pois Virgílio Afonso da Silva (2010) também refuta, com outros argumentos, a adoção de tais "princípios" 5 .

Müller (2005) rejeita os aspectos do "sistema de direitos fundamentais" e da Constituição enquanto "sistema de valores ou ordem de valores" enquanto metódica de direito constitucional. 0 imperativo da interpretação conforme a Constituição é um elemento da interpretação, ao lado de outros. 0 critério da correção funcional "afirma que a instância concretizadora não pode modificar a distribuição constitucionalmente normatizada das funções. 0 decisivo é a diferenciação racional e a controlabilidade dos elementos de concretização" (MÜLLER, 2005, p. 72). Estes últimos critérios não estão sendo estruturados no caso do RE 673707, pois não houve uma afronta de uma lei ante a Constituição, tampouco um questionamento/dúvida de correção funcional. O RE 673.707 se insurge contra uma decisão administrativa de um órgão governamental que negou à impetrante o acesso aos seus dados. 0 suporte fático do caso jurídico faz parte dos elementos do âmbito da norma.

0 âmbito da norma, o recorte da realidade social que tem seu âmbito de regulação, observa que para a concretização do direito, "direito" e "realidade" são em princípio eficazes no mesmo grau hierárquico (MÜLLER, 2005, p. 43-44). 0 exame do âmbito da norma engloba o contexto das estruturas materiais e também deve ser ater ao "valor" a ser concretizado, "que, porém, pode ser assim melhor racionalizado, em vez de ser executa- 
do de modo especulativo ou nos moldes de postulados" (MÜLLER, 2011, p. 241). Com esta metódica, "A legitimidade jurídico-constitucional das concepções axiológicas pode, dessa maneira, ser inserida na concretização da norma de um modo mais passível de comprovação do que a partir de uma compreensão não metódica da norma" (MÜLLER, 2011, p. 241). De fato, parece que Müller quer incluir no âmbito da norma as reflexões das premissas teóricas que subsidiam o texto da norma, pois "o âmbito normativo continua sendo, também nesse contexto que engloba valores, um elemento constitutivo da normatividade materialmente determinada e continua permanecendo a seu serviço e não a serviço do sociologismo ou do existencialismo jurídico" (MÜLLER, 2011, p. 241).

Neste tom, é irrefutável que o texto normativo do habeas data goza de um status de garantia constitucional. 0 habeas data configura uma das formas de proteção do jurisdicionado dentro do processo judicial. Esta conclusão converge com a coerência do topos sistemático anteriormente aduzido. A Constituição do atual Estado Constitucional cria as bases, determina os fundamentos, os objetivos e os princípios do ordenamento jurídico, estabelece os direitos e garantias para resolver os conflitos no interior da Sociedade, regula a organização e o procedimento de formação da unidade política e a atuação estatal. Como aduz Gilmar Ferreira Mendes (2014), a dogmática constitucional tende a denominar de garantias constitucionais um elenco de proteções que constam na Constituição que tem por objetivo a proteção do indivíduo no contexto do processo judicial. Isso porque, consoante André Ramos (2012), a inclusão de direitos fundamentais no texto normativo da Constituição não é suficiente para a sua fruição, sendo imprescindível que se tutele tais direitos em situações nas quais podem ser violados. A própria expressão do Título II da Constituição de 1988 “Dos Direitos e Garantias Fundamentais”, como pondera Anderson Cavalcante Lobato (1996), reclama a intelecção de que há uma previsão não de só direitos, mas também de certos mecanismos jurídicos e jurisdicionais que lhes possam dar efetividade e concretização. Tais mecanismos podem configurar a "jurisdição constitucional das liberdades", na literatura de Mauro Cappelleti, pois objetivam um processo constitucional especial para a proteção dos direitos fundamentais (LOBATO, 1996). 
José Afonso da Silva (2012) adverte que não se pode traçar uma linha de demarcação rígida de que os direitos são "declaratórios" e as garantias "assecuratórias", pois pode suceder que garantias são declaradas e, por vezes, são declarados direitos de maneira assecuratória. Parecer ser este o caso do habeas data, em que se declara um direito à proteção de dados pessoais por meio de uma garantia ao jurisdicionado no contexto do processo judicial.

Dentro dos elementos do âmbito da norma, o fator co-constitutivo da normatividade, a "realidade" do RE 673.707 revela que uma pessoa jurídica impetrou habeas data com o objetivo de "obter todas as informações relativas a débitos constantes em nome da empresa ora recorrente, bem como de todos os pagamentos efetuados que constem das bases de dados de apoio ao controle da arrecadação federal utilizadas pela Secretaria da Receita Federal, em especial o sistema SINCOR".

A inferência a ser realizada para a concretização constitucional do habeas data indica que o recorte da realidade social, a priori, co-constitui o primeiro "espaço de ação" do texto normativo do art. $5^{\circ}$, inciso LXXII, "a”. Na origem, o RE 673.707 é suscitado ante o Poder Judiciário (ivpublicidade do processo) para que se tenha a garantia do conhecimento (iii-faculdade jurídica exigível) das informações (i-objeto) relativas à impetrante (ii-legitimidade ativa) junto a um bancos de dados de entidade governamental- Secretaria da Receita Federal (ii-legitimidade passiva).

Quanto aos elementos dogmáticos, Müller (2005, p. 83-84) sublinha que são compostos pelos enunciados da jurisprudência pertinente e da bibliografia. Compartilham o destino do programa da norma, do âmbito da norma e do teor literal da norma, de materiais legais, de modelos históricos de normas e do caso solucionado.

A dogmática jurídica da proteção de dados pessoais é definitivamente um dos temas de Direito que ganhou maior evidência no fim do passado século XX e início do Século XXI. A leitura do texto de Vieira de Andrade "Os direitos fundamentais do século XXI" (2006, p. 1052-1055) permite que inserir este direito no âmbito de proteção da "dignidade da pessoa contra os perigos que resultam das estruturas do poder na sociedade [...] contra a explosão dos fenômenos de tratamento automatizado, conexão, transmissão e utilização de dados pessoais". 
É usual radicar uma das primeiras reflexões do direito à proteção de dados pessoais no conceito de privacy, proposta por Allan Westin em 1967, que a define como sendo o direito dos indivíduos, grupos ou instituições para determinar por si mesmos, quando, como e com qual extensão a informação acerca deles pode ser ou não comunicada (LOPÉZ DÍAZ, 1996; DONEDA, 2006; ZANON, 2013). Ainda, André de Carvalho Ramos (2005) indica que em 1974 Mclauglin e Vaupel publicaram o texto em que apontam o risco à intimidade e de discriminação pela existência dos "credit bureaus" sobre o comportamento do consumidor, cujas informações eram vendidas para fornecedores e direcionavam crédito e outras decisões.

A resposta legislativa sobre a proteção dos dados pessoais pode ser categorizada em fases (DONEDA, 2006). A inicial se caracteriza pelo rigor na criação dos arquivos informatizados, com princípios de proteção amplos e abstratos, centrados na atividade do processamento de dados, com regras dirigidas aos agentes do processamento (LIMBERGER, 2008). Tratou-se, na verdade, dos bancos de dados e não de privacidade (DONEDA, 2011). Diante da ampliação dos centros de processamento de dados, as leis se tornaram obsoletas, o que gerou ineficácia de um controle baseado em normas que estabeleciam minuciosamente alguns aspectos do funcionamento dos bancos de dados. A lei do Land Hesse, de 07.10.1970, na Alemanha é a primeira a regular a proteção dos dados informatizados de titularidade pública (ATHENIENSE, 2002). A lei posterior, de 27.01.1977, disciplinou os arquivos públicos e privados. Ainda, impende apontar os Fair Information Principles que tiveram sua origem na década de 70 nos USA (Advisory Commitee on Automated Personal Data Systems-1973), Reino Unido (Comitê de Privacidade-Organizações Privadas-1973) e Alemanha (Lei do Estado de Hesse-1975): princípio da finalidade; princípio da publicidade/transparência (accountability dos bancos de dados); princípio do consentimento; princípio da qualidade/ não excesso (acesso, retificação e cancelamento dos dados); princípio da segurança física; princípio da responsabilidade (MENDES, 2014). Ademais, é de se anotar o Privacy Act of 1974, que estabeleceu um código de boas práticas para regulamentar a recolha, manutenção, utilização e 
divulgação de informações sobre indivíduos mantidas em sistemas de registros por agências federais.

A segunda fase se compõe de normas menos austeras para a criação de arquivos e fundamentadas na proteção dos dados pessoais como uma liberdade negativa e não mais no fenômeno computacional (LIMBERGER, 2000). Percebeu-se que o fornecimento de dados pessoais pelos cidadãos tinha se tornado indispensável para a sua efetiva participação na vida social. Tanto os entes privados como os públicos começaram a utilizar frequentemente os dados pessoais, motivo pelo qual o exercício puramente individual desta liberdade era fundamental para a própria socialização dos indivíduos. Como exemplos expoentes se cita a lei francesa de 06.01.1978, a lei suíça de 1981, a lei da Islândia de 26.05.1981 e a de Luxemburgo de 30.03.1979. Urge registrar a positivação no texto constitucional espanhol de 1978 (art. 18.4).

Inicia a terceira fase o Convênio de Estrasburgo, de 28.01.1981, com a pretensão de unificação do direito europeu. É uma tentativa de garantir os direitos e de não obstar o desenvolvimento da informática. Preocupa-se em garantir a liberdade de fornecer ou não os dados pessoais. Reconhece-se que tal rito envolve a participação do indivíduo na sociedade e leva em consideração o contexto no qual lhe é solicitado que revele seus dados, estabelecendo meios de proteção para as ocasiões em que sua liberdade de decidir é limitada. Assim estão a lei do Reino Unido de 12.07.1984, a lei alemã de 20.12.1990, a lei de Portugal de 20.04.1991, a lei espanhola de 31.10.1992 e a de 13.12.1999 e a lei italiana de 31.12.1996 (LIMBERGER, 2009).

Danilo Doneda $(2006,2011)$ identifica uma quarta geração das leis que se caracteriza por tentar equalizar as desvantagens da ênfase individual, além de disseminar o modelo das autoridades independentes, criar normas conexas específicas para alguns setores (saúde, crédito, consumo). Adverte que se vislumbra um modelo de proteção de dados pessoais com a leitura da Diretiva 95/46/CE, da Diretiva 2002/58/CE e da Carta dos Direitos Fundamentais da União Europeia de 7/12/2000 (art. $8^{\circ}$ ).

Há de se registrar neste itinerário: (i) 02013 OECD Privacy Guidelines, uma revisão das 1980 OECD Guidelines on the Protection of Privacy and Transborder Flows of Personal Data; (ii) a recente Diretiva 2016/680 
do Parlamento Europeu e do Conselho, de 27 de abril de 2016, relativa à proteção das pessoas singulares no que diz respeito ao tratamento de dados pessoais pelas autoridades competentes para efeitos de prevenção, investigação, detecção ou repressão de infrações penais ou execução de sanções penais, e à livre circulação desses dados; (iii) o Regulamento 2016/679 do Parlamento Europeu e do Conselho, de 27 de abril de 2016, relativo à proteção das pessoas singulares no que diz respeito ao tratamento de dados pessoais e à livre circulação desses dados e que revoga a Diretiva 95/46/CE (Regulamento Geral sobre a Proteção de Dados); o (iv) o Privacy Shield (que substitui o Safe Habor, declarado inválido em 2015 pelo Tribunal de Justiça da União Europeia), acordo transnacional firmado entre a União Europeia e os Estados Unidos para troca de dados.

Inobstante a importância da citada produção legiferante, é consenso sustentar que uma das principais contribuições para a configuração jurídica da "autodeterminação informativa" é a decisão de 15 de dezembro de 1983 do Tribunal Constitucional alemão, sobre a Lei do Censo da população. 0 teor deste julgado concebeu a "autodeterminação informativa", como a autonomia que a pessoa tem de determinar quem, o que, e em que ocasião pode conhecer e/ou utilizar dados que lhe afetam. 0 reconhecimento do direito à autodeterminação informativa decorreu da interpretação constitucional realizada pelo Alto Tribunal alemão (art. $1.1 \mathrm{c} / \mathrm{c}$ art. 2.1, da Lei Fundamental) sobre o livre desenvolvimento da personalidade, o direito geral da personalidade e a dignidade da pessoa humana (CUEVA, 2012).

Com efeito, foi se formando uma doutrina brasileira que opina pela existência de um direito à proteção de dados pessoais ou de um direito à autodeterminação informativa. Percebe-se que alguns autores manejam com fungibilidade as duas expressões, conforme observa João Carlos Zanon (2013). Entretanto, “dado" há ser entendido como a informação em potencial (pré-informação), que pode se converter em informação se for comunicado, recebido e compreendido (DONEDA, 2011; MENDES, 2014). "Informação" alude a algo além da representação contida no dado (cognição), que se apresentar sob diversas formas, como a gráfica, fotográfica e acústica, etc (DONEDA, 2011; MENDES, 2014). Rodolfo Daniel Uicich (1999) distingue entre (a) dado anônimo: dado estatístico ou geral que 
não personaliza nem permite a personalização; (b) dado nominativo, referente a uma pessoa determinada, (b1) dado nominativo direto, quando permite a identificação sem necessidade de nenhum processo, (b2) dado nominativo indireto, quando permite a identificação com processamento de dados; (c) dado nominativo sensível, afeta ou pode afetar intimidade; (d) dado nominativo não sensível, é pessoal, está destinado a ser público (documento de identidade).

Laura Mendes (2014), com estamento nas normatizações europeias (especialmente as alemãs), configura o conceito de dados pessoais com "fatos, comunicações e ações que se referem a circunstâncias pessoais ou materiais de um indivíduo identificado ou identificável". E a informação pessoal "difere de outras informações por possuir um vínculo objetivo com a pessoa, isto é, por revelar aspectos que lhe dizem respeito". Por isso é que os dados que se refiram a pessoas indeterminadas podem ser considerados dados anônimos, e, por conseguinte, não mais sujeitos à proteção de dados pessoais se tratados de maneira a impossibilitar a identificação pessoal.

Antonio Enrique Pérez Luño $(1981,2005,2009)$ aposta na metamorfose do direito à intimidade para incluir a proteção de dados pessoais em seu âmbito de proteção. Advoga que o conceito de intimidade emergiu do filosófico foro interno, intrassubjetivo, estático, da interioridade ao foro externo, dinâmico, prático, da alteridade, respeitadas suas implicações intersubjetivas. À delimitação conceitual do direito à intimidade, antes referido como a faculdade de se isolar, adicionou-se, portanto, o poder de controle sobre as informações/dados pessoais. Tal dilatação conceitual se conecta a capacidade de interação da pessoa humana, assumindo esta uma postura de sujeito socializado, que não renuncia, igualmente, a sua individualidade.

Pablo Lucas Murillo de la Cueva (1990, 1999, 2004, 2007, 2009) afirma que o direito à autodeterminação informativa se construiu a partir da noção de intimidade, mas é autônomo em relação a esta. Defende o tratamento diferenciado destes dois direitos, para que os problemas específicos que suscitam a informática invoquem a defesa jurídica dos dados pessoais desde uma posição de independência sistemática com relação a outros perfis da intimidade. 
Danilo Doneda (2008) observa que a proteção de dados pessoais no Brasil pode ser prevista em disposições que convergem com a cláusula geral de proteção a pessoa humana. A proteção de dados pessoais é, portanto, uma garantia de caráter instrumental, derivada da tutela da privacidade, porém não limitada por esta, e que faz referência a um leque de garantias fundamentais que se encontram no ordenamento brasileiro (DONEDA, 2006). A proteção de dados pessoais está na inteligência dos artigos $1^{\circ}$, II e III; $3^{\circ}$, III; 5 , X, XI, XII, LXXII da Constituição de 1988. Não descuida Doneda (2006) de citar vários textos normativos que de alguma forma protegem a inviolabilidade da vida privada.

Não sem razão Laura Mendes (2014) afirma que o direito à proteção de dados pessoais deve-se pautar no cumprimento dos seguintes princípios: finalidade, esquecimento, qualidade dos dados, transparência e consentimento. Tal assertiva se justifica pelo argumento de que a concretização do direito à proteção de dados pessoais exige que o titular tenha efetivo controle sobre a circulação dos seus dados na sociedade, o que somente pode ser alcançado por meio da garantia dos seguintes direitos subjetivos do titular: (i) direito geral de informação, (ii) direito de acesso, (iii) direito de notificação, (iv) direito de retificação, cancelamento e bloqueio dos dados, (v) direito de não ficar sujeito a uma decisão individual automatizada. Em linha de pensamento semelhante, João Carlos Zanon (2013) admite que o direito à proteção dos dados pessoais é composto por direitos subjetivos: (i) direitos à informação, (ii) direitos de controle, (iii) direitos à abstenção e (iv) direito à indenização.

A perspectiva protetiva de dados pessoais já foi ressaltada por Marcel Leonardi (2011) ao categorizar em quatro os conceitos unitários de privacidade, para logo após defender um conceito plural. Leonardi (2011) invoca a postura de Westin entre os quatro primeiros conceitos que integram este último, pautada na razão de que o atributo básico do direito à privacidade era a capacidade de controle da circulação de informações e dados pessoais. Leonardi (2011, p. 51) observa que as várias das tentativas em estabelecer um conceito unívoco de privacidade se sustentam no método tradicional da definição per genus et differentiam, que acolhe ou refuta as hipóteses conceituais conforme sua coerência, lógica e consistência. Denuncia que a problematização deste procedimento 
conduz a conceitos ora extremadamente restritivos, ora abusivamente abrangentes. Propõe, portanto, um conceito plural de privacidade, baseado em José Afonso da Silva e Stéfano Rodotà.

Para Rodotà (2008, p. 109) há de se prevalecer uma concepção que se vocacione no "direito manter o controle sobre as próprias informações e de determinar as modalidades de construção da própria esfera privada. 0 objeto deste direito pode ser identificado no "patrimônio informativo atual ou potencial' de um sujeito" (grifo no original). Sobre este conceito, também adotado por Danilo Doneda (2006, p. 147), lê-se que a informação exsurge como mediadora entre a vida privada e o livre desenvolvimento da personalidade.

Nesta linha de raciocínio, o reconhecimento da proteção de dados pessoais como direito fundamental pode ser lido no texto constitucional brasileiro sob duas vertentes, seja pela posição da "dinâmica da intimidade" de Pérez Luño (2005), seja pela autonomia defendida por Pablo Lucas Murillo de la Cueva (1990). Ao alinhar-se à proposta doutrinária de Pérez Luño (2005), há de se reconhecer o direito fundamental à proteção de dados pessoais dentro de um conceito unívoco, evolutivo e de indeterminação semântica de intimidade, pela conjugação do âmbito de proteção do inciso III, do art. $1^{\circ}$ (dignidade da pessoa humana), do inciso X (vida privada) e do inciso LXXII (habeas data) ambos do art. 5ํㅡㅁ da CF-88. Partindo da perspectiva defendida por Pablo Lucas Murillo de la Cueva, como um direito fundamental autônomo, é de se reconhecer o direito fundamental à proteção de dados pessoais com fundamento no art. 5oㅡ $§ 2^{\circ}$, da CF-88. Nesta ótica, o direito fundamental à proteção dos dados pessoais seria um direito fundamental atípico, na nomenclatura de Jorge Bacelar Gouveia (1995), ou um direito fundamental implícito, na literatura de Ingo Sarlet (2004).

Um dos instrumentos de defesa do direito à proteção de dados pessoais, como intuitivo, é o habeas data. Entretanto, na visão de Danilo Doneda (2008), o habeas data na época em que foi concebido parece não ter sido influenciado pelas legislações estadunidenses e europeias ligadas à tecnologia de processamento de dados. As correlações mais imediatas se reportam aos dois países europeus de constitucionalimo democrático pós-guerras tardio: Portugal (1976) e Espanha (1978) (DONEDA, 2008). 
O habeas data, na leitura de Carlos Ari Sundfield, possui finalidade dúplice: (i) "assegurar o direito à obtenção da informação" e, (ii) "garantir o direito contra a informação ou contra seu uso inadequado" (SUNDFELD, 2011, p. 169). Este "remédio constitucional" é reconhecido pela doutrina de José Afonso da Silva, seu idealizador no texto constitucional, como:

[...] um remédio constitucional que tem por objetivo proteger a esfera íntima dos indivíduos contra: (a) usos abusivos de registros de dados pessoais coletados por meios fraudulentos, desleais ou ilícitos; (b) introdução nesses registros de dados sensíveis (assim chamados os de origem racial, opinião política, filosófica ou religiosa, filiação partidária e sindical, orientação sexual etc.); (c) conservação de dados falsos ou com fins diversos dos autorizados em lei. (SILVA, 2012, p. 453).

Para atingir esta finalidade, regular o direito de acesso a informações e disciplinar o rito processual do habeas data, foi aprovada a Lei no 9.507 , de 12 de novembro de 1997 que divide-se implicitamente em duas partes: i) regramento da fase extrajudicial, ii) regras processuais sobre a ação judicial. Nada se dispõe sobre direito material a ser garantido. A referida lei ateve-se a conceituar "caráter público" o qual exige uma pressuposição da possibilidade de transmissão das informações a terceiros ou que o uso não seja privativo do depositário das informações. Previu também a exigência de requerimento administrativo junto ao órgão detentor dos dados a que se busca conhecimento, regulando inclusive prazos e o acesso. A lei do habeas data trouxe, em síntese, a regulação deste remédio constitucional cuidando dos aspectos processuais, inclusive exigindo a demonstração da pretensão resistida quando da impetração desta garantia, anexada à petição inicial (art. $\left.8^{\circ}\right)$.

Há quem inclua no conceito do habeas data o direito personalíssimo do titular a controlar as informações/dados pessoais, constantes em registros públicos ou privados, e a manutenção, retificação, complementação, explicação e, ainda, de exclusão dessas informações (NIESS, 1990; ROTHENBURG, 1998; SILVA, 2009, 2012). 0 habeas data tutela o direito à proteção de dados pessoais, sensíveis ou não sensíveis, com reflexos nos direitos fundamentais à intimidade, à vida privada, à honra e à imagem das pessoas - art. 5ำ X, CF/88 (MOURÃO NETO, 2012). Destina-se 
à proteção da pessoa frente a bancos de dados públicos e privados com caráter público. 0 caráter púbico endereça a legitimidade passiva para as pessoas privadas que desempenham atividade privada e que passam, por força da Constituição, a ser obrigadas a prestar informações sobre os seus registros (STÜRMER, 1992).

Em que pese ter se prendido a aspectos processuais, a jurisprudência do STF vislumbra o habeas data para a proteção dos dados pessoais incluídos no conceito de privacidade (RHD 22/DF, relator: Min. Marco Aurélio, rel. p/acórdão: Min. Celso de Mello, julgado em 19/09/1991, Tribunal Pleno, DJ 01.09.1995; HD 90AgR /DF, rel.: Min. Ellen Gracie, julgado em 18.02.2010, Tribunal Pleno, DJe-050 de 18.03.2010, publicado em 19.03.2010; HD 92 AgR-AgR/DF, rel.: Min. Gilmar Mendes, julgado em 16/09/2010, Tribunal Pleno, DJe-190 de 07.10.2010, publicado em 08.10.2010). Conceitua-o como um "remédio jurídico-processual, de natureza constitucional, que se destina a garantir, em favor da pessoa interessada, o exercício de pretensão jurídica discernível em seu tríplice aspecto: (a) direito de acesso aos registros; (b) direito de retificação dos registros e (c) direito de complementação dos registros" (RHD22).

Contudo, o habeas data não pode ser manejado: (i) se não comprovada a pretensão resistida [art. 8, I, Lei 9.507/97] (RHD 22; RHD 24/DF, rel.: Min. Maurício Corrêa, julgado em 28.11.1996, Segunda Turma, DJ 13.02.1998; HD 87 AgR/DF, rel.: Min. Cármen Lúcia, Julgado em 25/11/2009, Tribunal Pleno, DJe-022 de 04.02.2010, publicado em 05.02.2010); (ii) para pleitear informações relativas a terceiros (HD 87 AgR; HD 92 AgR-AgR; RMS 24617/DF, Rel.: Min. Carlos Velloso, julgado em 17.05.2005, Segunda Turma, DJ de 10.06.2005); (iii) para obter informações ou vista de processo/procedimento administrativo (HD 92 AgR-AgR, HD 90 AgR, RMS 24617); (iv) para a remoção de matéria publicada em sítio eletrônico (HD 100 AgR/DF, Rel.: Min. Luiz Fux, julgado em 25.11.2014, Primeira Turma, DJe-246 de 15.12.2014, publicado em 16.12.2014).

O habeas data pode ser impetrado em desproveito (i) de entidades governamentais e (ii) de entidades que administrem registro ou banco de dados contendo informações que sejam ou que possam ser transmitidas a terceiros ou que não sejam de uso privativo do órgão ou entidade 
produtora ou depositária das informações [art. $1^{\circ}$, par. Ún., Lei 9.507/97] (RE165.304/MG, rel.: Min. Octavio Gallotti, julgado em 19.10.2000, Tribunal Pleno, DJ 15.12.2000).

As perspectivas dos elementos dogmáticos (doutrina e jurisprudência) à concretização constitucional do habeas data reforçam, portanto, que o recorte da realidade social do RE 6733.707 co-constitui o primeiro "espaço de ação" do programa normativo do art. $5^{\circ}$, inciso LXXII, "a”. O RE 673.707 é suscitado ante o Poder Judiciário (iv-publicidade do processo) para que se tenha a garantia do conhecimento (iii-faculdade jurídica exigível) das informações (i-objeto) relativas à impetrante (ii-legitimidade ativa) junto a um bancos de dados de entidade governamental-Secretaria da Receita Federal (ii-legitimidade passiva).

Müller rechaça o uso de elementos de teoria que não contribuam com a metódica constitucional. Alerta que podem produzir "efeitos reducionistas não somente em pormenores de conteúdo da concretização, mas também com vistas à compreensão do processo de concretização como totalidade" (MÜLLER, 2005, p.89). Por este motivo, convém seguir meticulosamente a proposta metodológica do referencial teórico adotado, sem tangenciar tais elementos.

Antes de avançar para os elementos de política constitucional, há de ser fazer algumas ressalvas sobre o direito à proteção de dados pessoais e o habeas data. Não se lê nos julgados do STF uma ênfase sobre o alcance/extensão do direito à proteção de dados pessoais protegido pelo habeas data, ainda que possa ser tal direito reconhecido. Mas este reconhecimento não autoriza a afirmação de que o habeas data atende a plenitude do direito à proteção de dados pessoais. "Acesso às informações", "Retificação" e "Complementação" não contemplam todas as implicações jurídicas protetivas do direito à proteção de dados pessoais. E isso se reflete na refutação, em parte, da hipótese de "vitalização" do habeas data como instrumento/garantia constitucional do direito fundamental à proteção de dados pessoais.

No RE 673707 a Corte Suprema fixou a seguinte tese ou norma de decisão: "O habeas data é a garantia constitucional adequada para a obtenção dos dados concernentes ao pagamento de tributos do próprio contribuinte constantes dos sistemas informatizados de apoio à ar- 
recadação dos órgãos da administração fazendária dos entes estatais." Majoritariamente, a doutrina inclui no direito à proteção de dados pessoais o efetivo controle sobre a circulação dos dados, o direito geral de informação, o amplo direito de acesso aos dados, o direito de notificação, o direito de retificação, cancelamento e bloqueio dos dados. Tanto o programa da norma como o âmbito da norma e a própria norma de decisão exarada pelo STF não contam um a amplitude de faculdades jurídicas que configurem um "efetivo controle" tal e como defendido e exposto nos elementos dogmáticos da doutrina acima.

De fato, o programa da norma do art. $5^{\circ}$, inciso LXXII, não exige a autorização para a coleta dos dados pessoais. Já se presume que os dados estão sob a guarda de "registros ou bancos de dados de entidades governamentais ou de caráter público" sem que o programa normativo outorgue o direito/faculdade jurídica de autorizar/permitir/consentir/ controlar este arquivamento ou sequer se impõe um "direito de notificação" ao titular pela coleta dos dados pessoais. Tampouco se inclui dentro do programa normativo a faculdade jurídica de se opor ou se abster ao tratamentos dos dados pessoais, cancelá-los ou bloqueá-los. E se não constam tais faculdades jurídicas no programa da norma, tampouco na concretização do âmbito da norma. Pode-se, pois, vislumbrar que o direito a proteção de dados pessoais pode ter o habeas data como uma de suas garantias, mas não a única.

Na verdade, as críticas à figura do habeas data ainda prevalescem, mesmo após o histórico deferimento do RE 673.707. Há objeções processuais: (i) de autores que já advogaram que o ordenamento jurídico já contava com mecanismos hábeis a satisfazer as pretensões atendidas pelo instituto (ROTHENBURG, W. C., 1998); (ii) que seu acesso é restrito, pois não admitido nos Juizados Especiais (LENOARDI, 2011, p. 206); e (iii) que para sua efetividade seria imperioso simplificar as formas de impetração, pois necessário advogado (DONEDA, 2008), além de ter de se avançar sobre como se interpreta as condições processuais dessa ação (MENDES, 2014). Há ainda uma objeção substantiva: o seu reduzido alcance pelo maniqueísmo protetivo do binômio acesso/retificação, ao ponto de Danilo Doneda (2008, p. 18-28) afirmar que "é forçoso concluir 
que o Habeas data brasileiro não se presta absolutamente à proteção de dados pessoais no cenário pautado pela Sociedade da Informação."

0 deferimento do RE 673.707, a despeito de sua relevância, não refuta nenhuma destas objeções processuais e substantivas. Pelo contrário. Tanto o Min. Relator Luiz Fux como o Min. Gilmar Mendes recordam que a Lei de Acesso à Informação, Lei no 12.527, publicada em 18 de novembro de 2011, é mais efetiva que a garantia constitucional do habeas data. Mas ao comentar sobre o mérito da legislação não diretamente vinculada à Lei do objeto deste escrito, estar-se-á a estruturar a concretização constitucional pelos elementos de política constitucional.

Os elementos de política constitucional contemplam as consequências de determinadas variantes de solução, pelos efeitos práticos não diretamente participantes do caso do ponto de vista da adequação à finalidade. Remete à pré-compreensão jurídica que leva à assunção de que o legislador teria, com prescrições, instituído decisões em princípio conformes à finalidade ou ao menos argumentativamente defensáveis com vistas à implementação prática de normas constitucionais (MÜLLER, 2005, p. 90).

Ao estruturar a concretização do habeas data com os elementos de política constitucional se verá que o direito à proteção de dados pessoais pode ser lido não só na Lei do habea data, mas principalmente na legislação esparsa (Lei 8.078/1990 e o Decreto 2.181/97, Lei no 9.296/1996, Lei no 9.613/1998 alterada pela Lei 12.683/2012, Lei Complementar no 105/2001, Lei 10.406/2002, Lei no 12.414/2011 e o Decreto 7.829/2012, Lei ${ }^{\circ} 12.527 / 2011$ e o Decreto 7.724/2012, Lei ํo 12.737/2012, Lei № 12.965/2014 e o Decreto 8771/2016). Com a análise de determinadas variantes de solução, cabe examinar que muito embora instituído pelo poder constituinte e disciplinado pelo poder constituído o habeas data teve e tem importância diminuta na proteção dados pessoais. E com isto cabe configurar uma objeção orgânica.

Para esta objeção orgânica, importantes são a Lei $n^{\circ} 12.527$, de $18 / 11 / 2011$ (LAI) [que regula o acesso a informações previsto no inciso XXXIII do art. $5^{\circ}$, no inciso II do $\S 3^{\circ}$ do art. 37 e no $\S 2^{\circ}$ do art. 216 da Constituição Federal; altera a Lei no 8.112, de 11 de dezembro de 1990; revoga a Lei $\mathrm{n}^{\circ} 11.111$, de 5 de maio de 2005, e dispositivos da 
Lei no 8.159, de 8 de janeiro de 1991] e o Decreto 7.724, de 16/05/2012 (Dec7724). A LAI inclui "dado" no conceito de informação (art. 4 I), e conceitua informação pessoal como sendo "aquela relacionada à pessoa natural identificada ou identificável” (art. $4^{\circ}$, IV). 0 Dec7724 diz que informação pessoal é a "relacionada à pessoa natural identificada ou identificável, relativa à intimidade, vida privada, honra e imagem" (art. $\left.3^{\circ}, \mathrm{V}\right)$. O inciso III, do artigo 6을 da LAI protege a informação pessoal "observada a sua disponibilidade, autenticidade, integridade e eventual restrição de acesso". A LAI no Capítulo IV (Das restrições de acesso à informação) dedica a Seção V para a proteção das informações pessoais. O Dec7724 direciona o Capítulo VII para este fim. As duas leis responsabilizam o agente público ou militar que divulgar ou permitir a divulgação ou acessar ou permitir acesso indevido à informação pessoal (art. 32, IV, da LAI; art. 65, IV, do Dec7724). Além disso, a LAI prevê que os órgãos e entidades públicas respondem diretamente pela negativa de acesso às informações, pelos danos causados em decorrência da divulgação não autorizada ou utilização indevida de informações pessoais, cabendo a apuração de responsabilidade funcional nos casos de dolo ou culpa, assegurado o respectivo direito de regresso. Aplica-se também esta responsabilidade à pessoa física ou entidade privada que, em virtude de vínculo de qualquer natureza com órgãos ou entidades, tenha acesso a informação pessoal e a submeta a tratamento indevido (art. 34).

Com esta brevíssima apreciação, e a despeito de não ser seu objeto a proteção de dados pessoais, reputa-se mais coerente o recurso à LAI para a salvaguarda deste direito do que à garantia constitucional prevista para tanto. Somente se negado o acesso à informação poder-se-ia suscitar a impetração do habeas data. Logo, a garantia constitucional é subsidiária ou residual na análise dos elementos de política constitucional para a concretização constitucional em deslinde, o que resulta das objeções processuais, substantivas e da orgânica.

Ademais, registre-se que para não fugir do objeto e do objetivo, este texto se circunscreveu ao exame de dados pessoais sob a guarda de "registros ou bancos de dados de entidades governamentais ou de caráter público". A amplitude e o risco das vulnerações aos dados pessoais no âmbito empresarial/privado na Internet é abissalmente maior. 
Com efeito, ao deslocar a tematização para os registros ou bancos de dados de entidades privadas ou de caráter privado, o enfoque do habeas data é despiciendo. Uma consulta aos domínios registrados no Brasil, verifica-se que 93,73\% são de titularidade de genéricos (com.br, eco.br, emp.br, net.br) (NIC.BR, 2018). Parece ser a tutela dos dados pessoais no meio privado a significante proteção que há de ser enfrentada pelo Direito. Disso deflui que os dados pessoais na Internet é uma demanda que reclama uma decisiva atenção da proteção jurídica, mas que não pode ser alcançada, absolutamente, pelo habeas data.

As objeções processuais, substantivas e a orgânica desconstituem a hipótese de "vitalização" do habeas data como instrumento/garantia constitucional do direito fundamental à proteção de dados pessoais. Pode-se vislumbrar que o direito a proteção de dados pessoais pode ter o habeas data como uma de suas garantias, mas na atual realidade constitucional, com um papel subsidiário ou residual.

\section{CONCLUSÕES}

Para responder ao objetivo proposto, de examiner a concretização do habeas data como garantia constitucional do direito fundamental à proteção dos dados pessoais, a partir da análise de um recorte da realidade na jurisprudência do STF, o itinerário metódico estruturante de Friedrich Müller leva a se chegar às seguintes conclusões:

1) Os elementos metodológicos strictiore sensu para a concreção constitucional do habeas data indicam que o recorte da realidade social do RE 673.707 está contemplado no primeiro "espaço de ação" do texto normativo do art. $5^{\circ}$, inciso LXXII, "a". Isso porque na origem do RE 673.707 se requereu ante o Poder Judiciário (iv-publicidade do processo) a garantia do conhecimento (iii-faculdade jurídica exigível) das informações (i-objeto) relativas à impetrante (ii-legitimidade ativa) junto a um bancos de dados de entidade governamental- Secretaria da Receita Federal (ii-legitimidade passiva). Ainda que indeferidos pela forma como foram impetrados, verifica-se que nos três primeiros casos submetidos pela ação constitucional do habeas data (RHD22, RHD24, HD18-Q0) há 
uma coerência argumentativa histórica e genética com o RE 673.707. Foram manjeados ante o Poder Judiciário (iv-publicidade do processo) para se ter a garantia do conhecimento (iii-faculdade jurídica exigível) de informações (i-objeto) relativas aos impetrantes (ii-legitimidade ativa) junto a um bancos de dados de entidade governamental- no caso a SNI (iilegitimidade passiva). É iniludível que os elementos histórico e genético reforçam o elemento gramatical e apresentam os contornos do âmbito da norma. 0 elemento sistemático conflui com as inferências protetivas de concretização obtidas mediante o processo estruturante de interpretação gramatical, histórica, genética no tratamento do texto da norma. O habeas data está inserto com as demais garantias constitucionais no Capítulo I (Dos Direitos e Deveres Individuais e Coletivos) do Título II (Dos Direitos e Garantias Fundamentais) da Constituição de 1988. Tantos os incisos do art. $5^{\circ}$ que o antecedem como o inciso que sucede o texto da norma do habeas data se referem às garantias fundamentais (habeas corpus; mandado de segurança, mandado de injunção e ação popular). 0 status de garantia fundamental do habeas data lhe impinge a qualificação de limite material de reforma constitucional, pois é uma das "cláusulas pétreas" (art. 60, § 4ํㅡㄴ, inciso IV). A co-constituição do texto da norma com o recorte da realidade suscitado no RE 673.707 parecem indicar uma confluência de "sentido e finalidade" o primeiro "espaço de ação" do texto normativo do art. 50, inciso LXXII, "a".

2) As perspectivas dos elementos dogmáticos (doutrina e jurisprudência do STF) à concretização constitucional do habeas data reforçam, portanto, que o recorte da realidade social co-constitui o primeiro "espaço de ação" do programa normativo do art. 50, inciso LXXII, "a". Contudo, tanto o programa da norma como o âmbito da norma e a própria norma de decisão exarada pelo STF não contam com a amplitude de faculdades jurídicas que configurem um "efetivo controle" tal e como defendido pela doutrina.

3) Ao estruturar a concretização do habeas data com os elementos de política constitucional se verá que o direito à proteção de dados pessoais pode ser lido não só na Lei do habea data, mas principalmente na legislação esparsa. Com a análise de determinadas variantes de solução, cabe examinar que muito embora instituído pelo poder constituinte e 
disciplinado pelo poder constituído o habeas data teve e tem importância diminuta na proteção dados pessoais.

4) Objeções processuais, substantivas e uma orgânica desconstituem a hipótese de "vitalização" do habeas data como instrumento/garantia constitucional do direito fundamental à proteção de dados pessoais. Pode-se vislumbrar que o direito a proteção de dados pessoais pode ter o habeas data como uma de suas garantias, mas na atual realidade constitucional, com um papel subsidiário ou residual.

\section{NOTAS}

1 Fermín Morales Prats, Catedrático do Departamento de Ciências Políticas e Direito Público da Universidade Autônoma de Barcelona, escreveu varios artigos sobre a proteção penal da intimidade. Em 1997, no dossiê La protección del derecho a la intimidad de las personas (fichero de datos), com o artigo "Protección de la intimidad: delitos e infracciones administrativas" afirmou que a ampliação da tutela da intimidade no Código Penal espanhol de 1995 se deu por fatores político-criminais, dentre os quais destacou: a) o desenvolvimento tecnológico das novas formas de controle do indivíduo; b) a recepção da cultura anglosaxã sobre o direito à privacy, incluindo o sentido positivo deste derecho e não só o negativo; c) a superação da teoria das esferas; d) o conteúdo amplo da intimidade (domiciliar, liberdade e confidencialidade de comunicações privadas). Aduz que que o art.18.4 da Constituição Espanhola reconhece assim a dimensão positiva da intimidade, convertida em liberdade informática, a qual constitui um direito de controle sobre os dados pessoais que circulam na sociedade informatizada. Opina pela importância da STC 254/93 de 20 de julho, além de fazer reflexões sobre a Diretiva 95/46, de 24 de outubro de 1995.

2 Nada obstante, Danilo Doneda (2008) não credita a Fermín Morales Prats a expressão habeas data. Doneda informa que em 1981, Vittorio Frosini identificou uma "liberdade informática", correlata à liberdade pessoal, uma exigência no contexto do desenvolvimento tecnológico. Ressalta o habeas corpus para a liberdade pessoal, e, arremata que: "poder-se-ia dizer, com uma paráfrase de caráter metafórico, que na legislação dos Estados modernos é necessário hoje um habeas data, um reconhecimento do direito do cidadão de dispor dos próprios dados pessoais, assim como ele tem o direito de dispor livremente do próprio corpo".

Danilo Doneda (2008) ainda se reporta a Stefano Rodotà, que em 1973 menciona o direito de acesso como um habeas scriptum, um sinônimo do habeas data. As alusões mais remotas ao termo "habeas data", segundo Doneda (2008), remontam-se a 1970: o artigo de Steven Weber na University of San Francisco Law Review denominado "Habeas data: the right of privacy versus computer surveillance"; além da afirmação de Alan Westin à revista National Geographic: "Talvez precisemos hoje de uma espécie de ação de < habeas data> - que obrigue tanto o governo como as corporações privadas a revelar as informações que eles coletaram e que estão utilizando para realizar julgamentos sobre um indivíduo e a justificar o porquê de fazê-lo".

3 Segundo Fernando Joaquim Ferreira Maia (2012) a proteção de dados pessoais no Brasil se deu basicamente pelo habeas data na Lei 9.507/97, na Argentina a Lei no 25.326/01, e na Colômbia a Lei Estatutária no 221/07.13 Entretanto, Maia (2012) observa que a regulação no Brasil não utilizou um dispositivo autônomo de proteção ampla de dados pessoais, como feito no ordenamento argentino. A tutela se dá com limitações: "conhecer informações e retificá-las, quando erradas, sobre a pessoa, mediante uma garantia individual".

Victor Bazán (2005) comenta que as Constituições de Brasil (art. 5, LXXII), Paraguai (art. 135), Peru (art. 200, inc. 3), Argentina (art. 43, parágrafo $3^{\circ}$ ) e Bolívia (art. 23) ressaltam o aspecto instrumental do habeas data. 
4 Em apertada síntese, Müller (2005, p. 71-79) sustenta que: a "Praticabilidade" está contida na interpretação teleológica; a "Interpretação a partir do nexo da história das ideias" e o "Quadro global de direito pré-constitucional” fazem parte da interpretação histórica; o "Critério de aferição do efeito integrante", a "Unidade da Constituição", o "Nexo de normas de direitos fundamentais e de normas de competência" são subcasos da interpretação sistemática e/ou política constitucional; a "Concordância prática" e a "Força normativa" fazem parte do "Efetividade dos direitos fundamentais", que estão insertos "Unidade da Constituição" (interpretação sistemática e/ou política constitucional.

5 Virgílio Afonso da Silva (2010) no texto "Interpretação constitucional e sincretismo metodológico" questiona a adoção pela doutrina brasileira dos "princípios" de interpretação constitucional suscitados por Konrad Hesse em seu manual de direito constitucional e dos métodos de interpretação constitucional relatados por Ernst-Wolfgang Böckenförde. Na sua análise, observa que não há indícios de que Hesse almejasse criar uma "teoria geral da interpretação constitucional" ao elencar no seu manual os "princípios": (1) unidade da Constituição; (2) concordância prática; (3) conformidade funcional; (4) efeito integrador e (5) força normativa da Constituição. Aduz que tais "princípios" são recepcionados no Brasil como se fossem uma "moeda corrente", mas que representam a sistematização das ideias de um único autor: Konrad Hesse. Reporta a ressonância de tais princípios da doutrina e na jurisprudências alemãs e relata que quase nenhum autor se depara com esta análise, mas quando há esta preocupação se referem ao "princípio da unidade da Constituição" no sentido de interpretação sistemática. Quando volta a sua atenção para a doutrina brasileira, Virgílio (2012) ressalta que alguns autores nacionais incluíram mais dois outros "princípios": o da "máxima efetividade" e o da "interpretação conforme a Constituição". E ao se deter em cada um destes "princípios", Virgílio (2012) reconhece que alguns deles não se diferenciam dos cânones tradicionais de interpretação, além de não haver possibilidade de "aplicação desses princípios em conjunto com outras práticas ou métodos de interpretação constitucional".

\section{REFERÊNCIAS}

ANDRADE, Vieira de. Os direitos fundamentais do século XXI. In: Congreso Iberoamericano de Derecho Constitucional: Derecho constitucional para el siglo XXI, 8, 2006, Sevilla / Universidad de Sevilla, Actas..., Navarra: Aranzadi, 2006, p.1052-1055.

ATHENIENSE, A. As transações eletrônicas e o direito de privacidade. Fórum Administrativo: Direito Público, Belo Horizonte, v. 2, n. 19, p. 1170-1177, set. 2002.

BAZÁN, Victor. El habeas data e o direito à autodeterminação informativa em perspectiva de direito comparado. Estudios Constitucionales, Chile, Ano 3, $\mathrm{n}^{\circ}$ 2, p. 85-139, 2005.

BRASIL, Ministério da Justiça. Conheça a nova versão do Anteprojeto de Lei de Proteção de Dados Pessoais. 21 de outubro de 2015. Disponível em: < http:// pensando.mj.gov.br/dadospessoais/>. Acesso em: 8 fev. 2018.

CARREIRA ALVIM, J. E. Habeas data. Rio de Janeiro: Forense, 2001. 
CERQUEIRA CÉSAR, Joaquim Portes. Garantia Constitucional do Habeas Data. Revista de Processo, vol. 61, p. 79-90, Jan-Mar, 1991.

CUEVA, Ricardo Villas Bôas. Há um direito à autodeterminação informativa no Brasil? In: MUSSI, Jorge; SALOMÃO, Luis Felipe; MAIA FILHO, Napoleão Nunes (Org.). Estudos jurídicos: em homenagem ao Ministro Cesar Asfor Rocha. Ribeirão Preto: Migalhas, 2012. v. 3. p. 220-241. Disponível em: <http://bdjur. stj.jus.br/dspace/handle/2011/48406>. Acesso em: 8 fev. 2018.

DALLARI, Dalmo de Abreu. 0 habeas data no sistema jurídico brasileiro. Revista da Faculdade de Direito, Universidade de São Paulo, [S.1.], v. 97, p. 239-253, jan. 2002. ISSN 2318-8235. Disponível em: <http://www.revistas.usp.br/rfdusp/ article/view/67544>. Acesso em: 8 fev. 2018. doi:http://dx.doi.org/10.11606/ issn.2318-8235.v97i0p239-253.

DONEDA, Danilo. Da privacidade à proteção dos dados pessoais. Rio de Janeiro: Renovar, 2006.

DONEDA, Danilo. Iguais mas separados: o Habeas data no ordenamento brasileiro e a proteção de dados pessoais. Cadernos da Escola de Direito e Relações Internacionais, n. 9, p. 14-33, 2008.

DONEDA, Danilo. A proteção dos dados pessoais como um direito fundamental. Espaço Jurídico Journal of Law, Joaçaba-SC, v. 12, n. 2, p. 91-108, jul./dez. 2011.

EUROPEAN COMISSION. Comission implementing decision of 12.7.2016, C(2016) 4176 final (Privacy Shield). Pursuant to Directive 95/46/EC of the European Parliament and of the Council on the adequacy of the protection provided by the EU-U.S. Privacy Shield. Brussels, 12 july 2016. Disponível em: <http://ec.europa.eu/justice/data-protection/files/privacy-shield-adequacy-decision_en.pdf>. Acesso em: 8 fev. 2018.

FOLGOSI, Rosolea M.; NUSDEO, Marcos F. O. Habeas Data. Doutrinas Essenciais de Direitos Humanos, vol. 5, p. 523 - 530, Ago. 2011.

GOUVEIA, Jorge Bacelar. Os direitos fundamentais atípicos. Aequitas Editorial Notícias: Lisboa, 1995. 
GUERRA FILHO, W. S. Habeas data frente a outros institutos de direito processual constitucional. Themis, Fortaleza, v. 1, n² 2, p. 229-248, 1998.

LEONARDI, Marcel. Tutela e privacidade na internet. São Paulo: Saraiva, 2011. Disponível em: <http://leonardi.adv.br/wp-content/uploads/2012/01/mltpi. pdf>. Acesso em: 8 fev. 2018.

LIMBERGER, Têmis. A informática e a proteção à intimidade. Revista de Direito Constitucional e Internacional, v.8, n.33, p.110-124, out./dez 2000.

LIMBERGER, Têmis. Da evolução do direito a ser deixado em paz, à proteção dos dados pessoais. Revista do Direito (UNISC), v. 30, p. 138-160, 2008.

LIMBERGER, Têmis. Da evolução do direito a ser deixado em paz, à proteção dos dados pessoais. Novos Estudos Jurídicos, v. 14, n. 2, p. 27-53, 2ํㅡadrimestre 2009.

LOBATO, Anderson Cavalcante. 0 reconhecimento e as garantias constitucionais dos direitos fundamentais. Revista de Informação Legislativa, ano 33, n. 129, p.85-98, jan./mar. 1996.

LOPÉZ DÍAZ, E. El derecho al honor y el derecho a la intimidad: jurisprudencia y doctrina. Madrid: Dykinson, 1996.

MAIA, Fernando Joaquim Ferreira. O Habeas data e a tutela da dignidade da pessoa humana na vida privada. Revista de Direitos e Garantias Fundamentais, Vitória, n. 12, p. 269-303, jul./ dez. 2012.

MENDES, Gilmar Ferreira. Direitos fundamentais de caráter judicial e garantias constitucionais do processo. In: MENDES, G. F.; BRANCO, P. G. Curso de Direito Constiucional. 9. ed. São Paulo: Saraiva, 2014, p. 396-626.

MENDES, Laura S. Privacidade, proteção de dados pessoais e defesa do consumidor: linhas gerais de um novo direito fundamental [e-book]. São Paulo: Saraiva, 2014.

MORALES PRATS, Fermín. Protección de la intimidad: delitos e infracciones administrativas, Cuadernos de Derecho Judicial, №. 13, (Ejemplar dedicado 
a: La protección del derecho a la intimidad de las personas - fichero de datos-, coordinado por José María Alvarez-Cienfuegos Suárez), p. 39-86, 1997.

MOURÃO NETO, Samuel Francisco. Arquivos de consumo (cadastros e bancos de dados de consumidores) e habeas data (individual e coletivo), 2012. Disponível em: <http://www.pucsp.br/tutelacoletiva/download/artigo_samuel. pdf>. Acesso em: 24 ago. 2016.

MÜLLER, Friedrich. Métodos de trabalho do Direito Constitucional. 3. ed. Rio de Janeiro: Renovar, 2005.

MÜLLER, Friedrich. Teoria Estruturante do Direito. 3. ed. São Paulo: RT, 2011.

MÜLLER, Friedrich. 0 novo paradigma do direito. 3. ed. São Paulo: RT, 2013.

MURILLO DE LA CUEVA, Pablo Lucas. El derecho a la autodeterminación informativa. Madrid: Editorial Tecnos, 1990.

MURILLO DE LA CUEVA, Pablo Lucas. La construcción del derecho a la autodeterminación informativa. Revista de estudios políticos, no104, p. 35-60, 1999.

MURILLO DE LA CUEVA, P. L. Derechos fundamentales y avances tecnológicos: Los riesgos del progreso. Boletín Mexicano de Derecho Comparado, no․ 109, p. $72-110,2004$.

MURILLO DE LA CUEVA, Pablo Lucas. Perspectivas del derecho a la autodeterminación informativa. IDP: revista de Internet, derecho y política $=$ revista d'Internet, dret i política, no. 5, 2007. Disponível em: <http://www.uoc.edu/ idp/5/dt/esp/lucas.pdf>. Acesso em: 8 fev. 2018.

MURILLO DE LA CUEVA, Pablo Lucas. La protección de los datos de carácter personal en el horizonte de 2010, Anuario de la Facultad de Derecho (Universidad de Alcalá), no․ 2, p. 131-142, 2009.

NIC.BR. Núlcleo de Informação e Coordenação do Ponto BR. Disponível em: <https://registro.br/estatisticas.html>. Acesso em: 8 fev. 2018.

NIESS, Pedro Henrique Távora. Considerações sobre o habeas data. Justitia (Ministério Público do Estado de São Paulo), São Paulo, ano 52, n 149, p. 38-53, 
jan./mar. 1990. Disponível em: <http://www.revistajustitia.com.br/revistas/ 4zxwxd.pdf> . Acesso em: 8 fev. 2018.

NUNES JÚNIOR, Vidal Serrano. Garantia constitucional para assegurar o acesso ou retificar informações relativas à própria pessoa, que constem em bancos de dados públicos ou de caráter público (art. $5^{\circ}$, LXXII). In: DIMOULIS, Dimitri [et all]. Dicionário Brasileiro de Direito Constitucional [ebook]. 2. ed. São Paulo: Saraiva, 2012.

PÉREZ LUÑO, A-E. Informática y libertad: Comentario al artículo 18.4 de la Constitución. Revista de estudios políticos, no 24, p. 31-54, 1981.

PÉREZ LUÑO, Antonio-Enrique. Derechos Humanos, Estado de Derecho y Constitución. Madrid: Tecnos, 2005.

PÉREZ LUÑO, A-E. La protección de los datos personales del menor en internet. Anuario Facultad de Derecho (Universidad de Alcalá), n 2, p. 143-175, 2009.

PINTO FILHO, Francisco Bilac Moreira. O segredo de Estado e as limitações do Habeas Data. Revista dos Tribunais, vol. 805, p. 34-59, nov. 2002.

RAMOS, A. C. O pequeno irmão que nos observa: os direitos dos consumidores e os bancos de dados de consumo no Brasil. Revista de Direito do Consumidor(RT), ano 14, n53, p.39-53, jan./mar. 2005.

RAMOS, Saulo. Parecer n 5 R. 71. DOU, 11 out. 1988, seção I, p. 19804. Disponível em: < http://www.agu.gov.br/page/atos/detalhe/idato/7917>. Acesso em: 8 fev. 2018.

ROTHENBURG, Walter Claudius. Réquiem para o habeas data (o habeas data e a nova Lei 9.507/97). In: ARRUDA ALVIM WAMBIER, T. (Coord.). Habeas data. São Paulo: RT, 1998.

REALE, Miguel. Lições preliminares de Direito. 27. ed. São Paulo: Saraiva, 2004.

SILVA, José Afonso. Comentário contextual à Constituição. 6.ed. São Paulo: Malheiros, 2009. 
SARLET, Ingo Wolfgang. Dignidade da pessoa humana e direitos fundamentais na Constituição Federal de 1988. 3. ed. Porto Alegre: Livraria do Advogado, 2004.

SILVA, José Afonso. Curso de direito constitucional positivo. 35.ed. São Paulo: Malheiros, 2012.

SILVA, Virgílio Afonso. Interpretação constitucional e sincretismo metodológico. In: SILVA, Virgílio Afonso. (Org.). Interpretação constitucional. 1 ed. $3^{\mathrm{a}}$ tir. São Paulo: Malheiros, 2010, p. 115-143.

SUNDFELD, Carlos Ari. "Habeas data" e mandado de segurança coletivo. Doutrinas Essenciais de Direitos Humanos, v. 5, p. 169-186, Ago - 2011.

STÜRMER, Bertram Antônio. Banco de dados e "habeas data" no código do consumidor. Revista de Direito do Consumidor, vol. 1, p. 55-94, Jan - Mar/1992.

TRIBUNAL DE JUSTIÇA EUROPEU. Processo C362/14. Luxemburgo, 6 de outubro de 2015. Disponível em: < http://curia.europa.eu/juris/documents. jsf?pro $=\& \operatorname{lgrec}=\mathrm{pt} \&$ nat $=$ or\&oqp $=\& \lg =\&$ dates $=\&$ language $=\mathrm{pt} \& \mathrm{jur}=\mathrm{C} \% 2 \mathrm{CT} \%$ 2CF\&cit=none $\% 252 \mathrm{CC} \% 252 \mathrm{CCJ} \% 252 \mathrm{CR} \% 252 \mathrm{C} 2008 \mathrm{E} \% 252 \mathrm{C} \% 252 \mathrm{C} \% 252 \mathrm{C}$ $\% 252 \mathrm{C} \% 252 \mathrm{C} \% 252 \mathrm{C} \% 252 \mathrm{C} \% 252 \mathrm{C} \% 252 \mathrm{C} \% 252 \mathrm{Ctrue} \% 252 \mathrm{Cfalse} \% 252 \mathrm{Cfal}-$ se\&num $=\mathrm{C}-362 \% 252 \mathrm{~F} 14 \& \mathrm{td}=\% 3 \mathrm{BALL} \& \mathrm{pcs}=0$ or\&avg $=\&$ page $=1 \& \mathrm{mat}=$ or $\& \mathrm{j}-$ ge $=\&$ for $=\&$ cid $=825572>$. Acesso em: 8 fev. 2018 .

UICICH, Rodolfo Daniel. Los bancos de datos y el derecho a la intimidad. Buenos Aires: Ad-Hoc, 1999.

UNITED NATIONS HUMAN RIGHTS COUNCIL. Agenda item 3, "The right to privacy in the digital age", Promotion and protection of all human rights, civil, political, economic, social and cultural rights, including the right to development. UN. New York, 24 March 2015. A/HRC/28/L.27. Disponível em: < http://ap.ohchr.org/documents/dpage_e.aspx?si=A/HRC/28/L.27>. Acesso em: 8 fev. 2018.

UNITED NATIONS HUMAN RIGHTS COUNCIL. Human Rights Council adopts two resolutions and closes its twenty-ninth regular session. UN. New York, 3 July 2015. Disponível em: <http://www.ohchr.org/EN/NewsEvents/Pages/ 
DisplayNews.aspx?NewsID=16200\&LangID=E\#sthash.rFJHVqb8.dpuf $>$. Acesso em: 8 fev. 2018.

UNITED NATIONS HUMAN RIGHTS COUNCIL. UN Special Rapporteur on the right to privacy. Annual Reports, UN. New York. Disponível em: < http://www. ohchr.org/EN/Issues/Privacy/SR/Pages/AnnualReports.aspx>. Acesso em: 8 fev. 2018.

UNITED NATIONS HUMAN RIGHTS COUNCIL. UN Special Rapporteur on the right to privacy. Planned Thematic Reports and call for consultations, UN. New York. Disponível em: < http://www.ohchr.org/EN/Issues/Privacy/SR/Pages/ ThematicReports.aspx>. Acesso em: 8 fev. 2018.

ZANON, João Carlos. Direito à proteção dos dados pessoais. São Paulo: RT, 2013.

Recebido em: 30-8-2016

Aprovado em: 20-6-2018

\section{Marco Aurélio Rodrigues da Cunha e Cruz}

Doutor em Direito Constitucional pela Universidad de Sevilla (título revalidado pela UFPE); professor titular do Mestrado em Direitos Fundamentais da Universidade do Oeste de Santa Catarina (PPGD | UNOESC); professor pesquisador da Escola Superior Associada de Goiânia (ESUP) e da Faculdade Cambury de Goiânia. E-mail: mar.cunhaecruz@gmail.com

\section{Matheus Felipe de Castro}

Doutor em Direito pela Universidade Federal de Santa Catarina; professor adjunto do Curso de Graduação em Direito da UFSC - Universidade Federal de Santa Catarina, Coordenador Acadêmico Adjunto e Professor Titular do Programa de Mestrado em Direitos Fundamentais da UNOESC - Universidade do Oeste de Santa Catarina, Pesquisador no Departament de Dret Privat, da UAB - Universitat Autònoma de Barcelona. E-mail: matheusfelipedecastro@gmail.com Programa de Pós-Graduação em Direito da Universidade do Oeste de Santa Catarina Rua Nereu Ramos, 3777-D, Bairro Seminário - Chapecó/SC - CEP: 89813-000 